\title{
EFFECT OF INTERCROPPING OF PEA WITH SOME MEDICINAL PLANTS ON MICROBIAL COMMUNITY OF SOIL, DAMPING-OFF AND DOWNY MILDEW DISEASES, UNDER BEHEIRA GOVERNORATE CONDITIONS Mohamed, Gehad M. \\ Vegetable Dis. Dept., Plant Pathology Res. Institute, ARC, Giza, Egypt:
}

\begin{abstract}
Isolation from diseased roots of pea plants collected from three locations at El Beheira governorate indicated that, the most frequently isolated fungi are Fusarium solani and $F$. oxysporum with the averages of $24.07 \%$ for both followed by Alternaria solani and Rhizoctonia solani with $14.81 \%$ and $F$. moniliforme with $9.26 \%$, respectively. The disease severity of downy mildew, caused by Peronspora viciae was recorded during 2007/2008 and 2008/2009 at Etay Elbaroud, Badr and Kom Hamada provinces and the averages were $28.37,22.24$ and $13.27 \%$, respectively. The essential oils of Cumin, Caraway and Anise showed the most reducing effect for the mycelial growth of $F$. solani, F. moniliforme and Sclerotium rolfsii in vitro with the averages of $70.99,21.92$ and $14.96 \%$, respectively. The highest significant reduction of the spores number of $F$. solani and $F$. moniliforme was observed with the essential oils of Cuminum cyminum, Carum carvi and Foenculum vulgare. In addition essential oils of $C$. cyminum and $C$. carvi reduced the number of sclerotia of $S$. rolfsii.

Intercropping of pea with medicinal plants was studied in field trials through two successive seasons. Cropping pattern side/side combination showed certain reduction of pea damping-off disease and disease severity of downy mildew than sole pea (check). Total damping-off was reduced using intercropping with $C$. carvi, $F$. vulgare and Pimpinella anisum compared with sole pea with averages of $39.19,48.00$ and $48.29 \%$ during $2007 / 2008$ and 33.46 , 39.33 and $40.33 \%$ during 2008/2009, respectively. Intercropping pea with medicinal plants $F$. vulgare, C. carvi, Anethum graveolens and $P$. anisum were more effective in decreasing disease severity of downy mildew with the averages of 20.20, 20.58, 21.27 and $22.83 \%$ during $2007 / 2008$, respectively compared with check (sole pea).

Pea intercropped with some medicinal plants could regulate soil microbial community such as actinomyces, bacteria and fungi effectively. The results showed that soil rizosphere was improved, and the fungal diversity differed. Fusarium spp. and $R$. solani were found only when pea intercropped with Cuminum cyminum and Nigella sativa. No familiar pathogens were found with intercropping with $C$. carvi, $F$. vulgare and $P$. anisum. The CFU of bacteria in case of intercropping with $C$. carvi and $N$. sativa was the highest during the two growth stages of pea, and that of actinomycets in all six intercropping treatments was increased during the flowering stage of pea. The use of intercropping system in pea with medicinal plants as a mean for natural disease control is discussed.

Intercropping pea with $C$. carvi increased pea fresh and dry weight in addition to the weight of 100 seeds for both seasons (2007/2008 and 2008/2009) more than other intercropping treatments and sole pea. In contrast, the intercropping with $C$. cyminum and $N$. sativa had the least values.
\end{abstract}

Keywords: Pea, essential oils, medicinal plants, intercropping, soil microbial community, downy mildew. 


\section{INTRODUCTION}

Pea (Pisum sativum L.) is a major annual pulse crop of temperate region of the world and was originally cultivated in the Mediterranean basin Smartt (1990) and Sardana et al. (2007). Pea crop is prone to a number of diseases such as rhizoctonia seedling blight, bacterial blight, acochyta foot rot, downy mildew, powder mildew, pythium blight, aphanomyces root rot, wilt and root rot diseases caused Fusarium species (Hagedorn, 1991).

Pea is one of the most important winter vegetable crops in Egypt. It grows well all over the Egyptian provinces and cultivated for green pods and dry seeds. Pea, like other cultivated crop, is susceptible to several diseases such as damping-off and root-rot caused by Rhizoctonia solani, Fusarium solani, F. oxysporum, F. moniliforme and Pythium debaryanum. (Nour-Jehan 2003).

Fusarium wilt, near wilt and root rot diseases are a major cases, this pathogen has caused partial to complete loss of pea crop and is capable of causing such damage to other crops as well ( Lestie and Summerell, 2006 and Smith, 2007).

Abdala et al. (1992) reported that Sclerotium rolfsii Sacc, Rhizoctonia solani Kuhn and Macrophomina phaseolina, (Tassi) Goid were the main soil borne pathogens responsible for causing damping-off and root rot diseases in grown pea plants.

Downy mildew has become the major disease of pea crop, especially in the northern governorates over the last decade causing significant losses in the yield of pea and its quality. Pea growers in Egypt has claimed that downy mildew diseases kills high numbers of their plants before flowering, in addition to the visible losses in the yield and its quality (Sahar 1995).

Plants have ability to synthesize aromatic secondary metabolites, like phenols, phenolic acids, quinones, flavones, flavonoids, flavonols, tannins and coumarins (Cown, 1999). The use of plant materials as fungicides is of a great importance and needs more attention (Boddle, 1982) and various plant products like gum, oils, resins etc. are used as fungicidal compounds. Some of the volatile oils, which often contain the principal aromatic and flavoring components of herbs and spices, have been recommended as plant based antimicrobials to retard microbial contamination and reduction in spoilage of food commodities (Malkhan, et al., 2012). Ozan (2003) proved antagonistic properties of some essential oils such as Sage, Laurel, Dill, Cumin, Fennel and Thyme in controlling Botrytis cinerea.

In addition, increased frequency of chemical application leads to development of pathogen resistant strains and accumulation of residues in produce and resulting in risks to health, environment, and non-target organisms (Burkett-Cadena et al., 2008).

Intercropping ideally allows for improved resource use and beneficial interactions between the crops. In the other words, light, water and nutrient are used by the crops instead to the weeds and some plants enhance the growing environment for their companion. Crop plant cultivar mixtures work to minimize the spread of plant diseases by reducing the quantity of susceptible host plants (Altieri, 1999 and Hauggaard et al., 2007). Benefits of 
intercropping include optimal use of resources, stabilization of yield, weed suppression, improved soil fertility conservation, and higher economic returns (Blaser et al., 2007 and Kabura et al., 2008). However, information on the role of intercropping on disease suppression is scanty.

Therefore, the objective of this study was to evaluate the efficacy of intercropping some medicinal plants with pea in the management of dampingoff and downy mildew diseases moreover, the effect of intercropping medicinal plants on the total count of microorganisms in the rizosphere of pea plants. Also, to evaluate the effect of some essential oils in vitro on the linear growth and sporulation of Fusarium solani, F. moniliforme and sclerotial formation of Sclerotium rolfsii. The study aimed to reduce the use of fungicides and the environmental pollution using the alternative methods for minimizing damping-off and downy mildew severity on pea by intercropping with some medicinal plants.

\section{MATERIALS AND METHODS}

\section{1- Survey of pea root rot and downy mildew diseases in different locations:}

Pea rotten roots and wilted plants were collected from different localities that cultivated with pea at El-Beheira governorate namely Bader, Etay El-Baroud and Kom Hamada. Survey was conducted during seasons 2007 / 2008 and 2008 / 2009. 10 samples of naturally infected roots were collected from each field and the isolation, purification and identification of the different pathogenic fungi associated with samples were carried out.

\section{a- Sampling and isolation from infected seedlings and roots:}

Infected parts were cut into small pieces, washed thoroughly with running water to remove any adhering soil particles. These pieces were surface sterilized by immersing in 5\% sodium hypocloride solution for $2 \mathrm{~min}$., then washed several times in sterilized water and dried between sterilized filter papers. Four surface sterilized pieces were aseptically transferred on potato dextrose agar medium (PDA). Plates were incubated at $27 \mathrm{C}^{\circ}$ for $3-7$ days and observations were recorded (Christensen, 1957). Hyphal-tip of grown fungi were transferred individually to new PDA plates (Riker and Riker, 1936) and then identified according to their morphological and microscopical characters as described by (Gilman, 1957 and Jens et al., 1991). Identification was confirmed by the Department of Mycology, Plant Pathology Institute, Agricultural Research Center, Giza, Egypt.

Downy mildew severity on pea was surveyed on plants of different cultivars grown in fields at El-Beheira governorate during autumn seasons of 2007/2008 and 2008/2009 with three locations, each location was represented with five fields. Downy mildew severity was monitored weekly starting from the appearance of first symptoms. Twenty samples were randomly collected from each field and the disease severity was calculated, using 0-9 rating scale based on the percentage of leaf area affected (Warkentin, et al. 1996), where $0=$ no infection, $1=<1 \%, 2=1-5 \%, 3=5-10 \%$, 
$4=10-20 \%, 5=20-40 \%, 6=40-60 \%, 7=60-80 \%, 8=80-90 \% .9=>90 \%$ of leaf area affected.

2- Effect of essential oils on the linear growth of the pathogens:

The effect of essential oils of Dill (Anethum graveolens L.), Caraway (Carum carvi L.), Cumin (Cuminum cyminum), Fennel (Foeniculum vulgare Mitter), Anise (Pimpinella anisum L.) and Black cumin (Nigella sativa L.) (Table 1) on the mycelial growth of the tested fungi namely Fusarium solani, $F$. moniliforme and Sclerotium rolfsii were carried out under laboratory conditions. The crude oils were added to autoclaved PDA medium at (10000 ppm) prior to pouring the media medium (Thakur et al., 1989). Amended medium was poured into sterilized Petri dishes of $9 \mathrm{~cm}$ diameter at the rate of $15 \mathrm{ml} /$ Petri dish and others without any essential oil were prepared and served as control. Petri dishes were inoculated with equal discs $(4 \mathrm{~mm}$ in diameter) of each tested fungi and incubated at $27^{\circ} \mathrm{C}$ and the linear growths were measured as mentioned by (Atia, 1995). Inhibition percentage of mycelial growth is evaluated by comparing the colony diameter of

poisoned plate (with essential oils) and non-poisoned plate and calculated using the formula given below (Das et al., 2010).

Mycelial inhibition $=$ Mycelial growth control - Mycelial growth treatment $\times 100$

$$
\text { Mycelial growth control }
$$

Table (1). Scientific, English, Arabic names of the plants, their oils and their families

\begin{tabular}{|c|c|c|c|}
\hline Scientific name & English name & Family & Arabic name \\
\hline Anethum graveolens & Dill & Apiaceae & شبت \\
\hline Carum carvi & Caraway & Apiaceae & كر اوية \\
\hline Cuminum cyminum & Cumin & Apiaceae & كمون \\
\hline Foenculum vulgare & Fennel & Apiaceae & شمر \\
\hline Pimpinella anisum & Anise & Apiaceae & 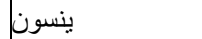 \\
\hline Nigella sativa & Black cumin & Ranunculaceae & حبة البركنة \\
\hline
\end{tabular}

3- Effect of essential oils on sporulation and sclerotial formation:

The tested fungi, F. solani, F. moniliforme and S. rolfsii were plated on PDA medium amended with the different essential oils and incubated for 10 days at $27 \mathrm{C}^{\circ}$

For $F$. solani and $F$. moniliforme spore suspensions were prepared by adding $10 \mathrm{ml}$ sterilized water and the average number of micro and macro conidia were recorded by using haemocytometer slide (Hansen, 1926) and $S$. rolfsii were observed for their different numbers of scleratia.

4- Field experiments:

These experiments were carried out in open field in Etay El-Baroud Agricultural Research Station at El-Beheira governorate during two successive growing seasons 2007/2008 and 2008/2009. The experiments were designed to study the effect of intercropping medical plants with pea cultivar Master B on damping-off and downy mildew. And also an the total count of microorganisms in the rhizosphere of pea roots. 
Experimental unit comprised four plots each plot had 4 rows (each 7 miter long and $0.7 \mathrm{~m}$ wide $=14.70 \mathrm{~m}^{2}$. Pea was sown in mid of October in $2007 / 2008$ and 2008/2009, three seeds/ hill and hills were spaced at $30 \mathrm{~cm}$ apart in east of row while, the west side was sown with alternative medicinal plants, i.e. Dill (A. graveolens L.), Caraway (C. carvi L.), Cumin (C. cyminum), Fennel ( $F$. vulgare Mitter), Anise ( $P$. anisum L.) and Black cumin ( $N$. sativa L.) control (as check) was sown with pea seed alone. In both seasons, the normal agricultural practices of growing pea including fertilization and irrigation were followed. The experiments design used was a randomized complete block design with four replications. Plants were left to natural infection with downy mildew during the growing seasons, plants were examined, and visually scored using 0-9 rating scale described above.

The recorded data were:

- The pre-emergence damping-off was assessed after 21 days from sowing.

- The post-emergence damping-off after 35 days from sowing.

- The fresh and dry weights were recorded after 50 days from sowing.

4.1- Effect of intercropping medicinal plants on the total count of microorganisms in the rhizosphere of pea roots:

The total numbers of cultivable bacteria, fungi and actinomyces were determined according to colony forming units (CFU) on agar plates using dilution plate methods. Microorganisms were counted in soil at two stages of plant growth; vegetative stage 30 days after sowing, and flowering stage 60 days after sowing. The root system was gently shaken to collect excessive adhering soil particles. Ten grams from these particles were added to 9 milliliter sterilized distilled water in a $250 \mathrm{ml}$. conical flask. They were shaken thoroughly on a mechanical shaker for 15 minutes. This approximately gave a dilution of $10^{-1}$ concentrations according to (Skinner et al., 1952). In order to investigate the presence of fungal genera, serial dilutions of soil suspensions were conducted to $10^{-3}$. One $\mathrm{ml}$ of the latter suspension was placed in a sterilized Petri-dish before pouring Martin 's medium (Martin, 1950).

To count the total bacteria existing in the rhizosphere, soil extract yeast agar medium, modified after (Skinner et al., 1952) was used, then one $\mathrm{ml}$ of the rhizoshere soil suspension was diluted till $10^{-6}$. One $\mathrm{ml}$ of the last dilution was plated on the soil extract yeast medium.

In order to count actinomycets, Jensen 's medium was used as mentioned by (Allen, 1953). One $\mathrm{ml}$ of the rhizosphere soil suspension $10^{-5}$ was placed in a sterilized Petri-dish before pouring Jensen 's medium, and incubated at $28^{\circ} \mathrm{C}$ for seven days.

\section{5- Statistical analyses:}

Data obtained were subjected to the statistical analysis according to the standard methods recommended by (Gomez and Gomez, 1984) using the computer program (costate). Means were compared using L.S.D. at the level $5 \%$ of probability. 


\section{RESULTS AND DISCUSSION}

\section{1- Survey of pea root rot and downy mildew diseases in different location:}

Results in Table (2) show that 108 isolates from soil borne fungi were isolated from rotten and wilted roots of pea plants cultivated at three locations from El-Beheira governorate. The collected isolates were identified and ranked in descending order as Fusarium oxysporum and F. solani (13) isolates which showed the highest frequency of $24.07 \%$ for both followed by Alternaria solani and $R$. solani (8) isolates with frequency of $14.81 \%$ for both then F. moniliforme (5) isolates, Pythium ultimum, Macrophomina phasolina (3) isolates and $S$. rolfsii (1) isolates with frequencies of 9.26, 5.56, 5.56 and $1.85 \%$, respectively. The number of isolated fungi was the highest with samples of Badr followed by Kom-Hamada and Etay-El baroud.

Table (2): Number of isolates (N) from rotten and wilted roots of pea and their frequency\% (F) of three locations at El-Beheira governorate.

\begin{tabular}{|l|c|c|c|c|c|c|c|c|}
\hline \multirow{2}{*}{ Lsolated fungi } & \multicolumn{2}{|c|}{ Etay-El baroud } & \multicolumn{2}{c|}{ Badr } & \multicolumn{2}{c|}{ Kom Hamada } & Total & $\begin{array}{c}\text { Average of } \\
\text { frequency }\end{array}$ \\
\cline { 2 - 9 } & $\mathrm{N}$ & $\mathrm{F} \%$ & $\mathrm{~N}$ & $\mathrm{~F} \%$ & $\mathrm{~N}$ & $\mathrm{~F} \%$ & $\mathrm{~N}$ & 14.81 \\
\hline A. solani & 2 & 14.29 & 4 & 16.67 & 2 & 12.50 & 8 & 24.07 \\
\hline F. solani & 1 & 7.14 & 6 & 25.00 & 6 & 37.50 & 13 & 24.07 \\
\hline F. oxysporum & 5 & 35.71 & 7 & 29.17 & 1 & 6.25 & 13 & 9.26 \\
\hline F. moniliforme & 1 & 7.14 & 3 & 12.5 & 1 & 6.25 & 5 & 5.56 \\
\hline M. phaseolina & 1 & 7.14 & 1 & 4.17 & 1 & 6.25 & 3 & 5.56 \\
\hline P. ultimum & 1 & 7.14 & 1 & 4.17 & 1 & 6.25 & 3 & 14.81 \\
\hline R. solani & 3 & 21.43 & 1 & 4.17 & 4 & 25.00 & 8 & 1.85 \\
\hline S. rolfsii & 0 & 0.00 & 1 & 4.17 & 0 & 0.00 & 1 & \\
\hline Total & 14 & & 24 & & 16 & & 54 & \\
\hline
\end{tabular}

F\%: Frequency $\%=\{$ number of isolated fungus $/$ Total $\} \times 100$

Downy mildew severity of pea was surveyed on plants of different cultivars grown in a commercial field at El-Beheira governorates, was represented by three locations under investigation during 2007/2008 and 2008/2009.

Data presented in Table (3) show that, values of disease severity during 2008/2009 were higher than those recorded during 2007/2008. Means of disease severity at the studied locations were significantly different and varied from 15.81 to $29.93 \%$ during $2^{\text {nd }}$ season $2008 / 2009$. But during the first season (2007/2008) means of disease severity incidence ranged from 10.72 to $26.8 \%$. 
Table (3): Survey of downy mildew severity of pea in field of three locations at El-Beheira during 2007/2008 and 2008/2009.

\begin{tabular}{|c|c|c|c|c|c|c|}
\hline \multirow[t]{2}{*}{ Province } & \multirow[t]{2}{*}{ Field } & \multicolumn{5}{|c|}{ Disease severity } \\
\hline & & 1st & Mean & 2nd & Mean & $\begin{array}{l}\text { Grand } \\
\text { Mean }\end{array}$ \\
\hline \multirow[t]{5}{*}{ Etay-Elbaroud } & F1 & 27.00 & \multirow[t]{5}{*}{26.80} & 32.1 & \multirow[t]{5}{*}{29.93} & \multirow[t]{5}{*}{28.37} \\
\hline & F2 & 28.00 & & 25.30 & & \\
\hline & F3 & 25.00 & & 28.50 & & \\
\hline & F4 & 28.25 & & 33.25 & & \\
\hline & F5 & 25.75 & & 30.50 & & \\
\hline \multirow[t]{6}{*}{ Badr } & & & & & & \\
\hline & F1 & 20.00 & \multirow[t]{5}{*}{19.74} & 27.70 & \multirow[t]{5}{*}{24.74} & \multirow[t]{5}{*}{22.24} \\
\hline & F2 & 15.00 & & 18.00 & & \\
\hline & F3 & 18.70 & & 25.00 & & \\
\hline & F4 & 25.00 & & 23.01 & & \\
\hline & F5 & 20.00 & & 30.00 & & \\
\hline \multirow[t]{6}{*}{ Kom Hamada } & & & & & & \\
\hline & F1 & 12.00 & \multirow[t]{5}{*}{10.72} & 17.30 & \multirow[t]{5}{*}{15.81} & \multirow[t]{5}{*}{13.27} \\
\hline & F2 & 10.10 & & 14.00 & & \\
\hline & F3 & 8.75 & & 19.00 & & \\
\hline & F4 & 12.25 & & 8.75 & & \\
\hline & F5 & 10.50 & & 20.00 & & \\
\hline Grand mean & & & 19.09 & & 23.49 & \\
\hline L.S.D at $5 \%=$ & \multirow{4}{*}{\multicolumn{6}{|c|}{$\begin{array}{l}2.93 \\
2.39 \\
\mathrm{Ns}\end{array}$}} \\
\hline Region & & & & & & \\
\hline Year & & & & & & \\
\hline Region $x$ Year & & & & & & \\
\hline
\end{tabular}

\section{2- Inhibitory effect of essential oils of medicinal plants on linear growth of some pathogenic fungi in vitro:}

Data in Table (4) and Fig. (1) indicate that essential oils of $C$. cyminum, C. carvi, $P$. anisum and $A$. graveolens gave the highest reduction with averages of $70.99,21.92,14.96$ and $13.83 \%$, respectively, whereas, the least effective essential oils in this respect were $F$. vulgare and $N$. sativa with the averages of 7.53 and $6.54 \%$, respectively. These results are in agreement with that obtained by (Bauiomy, 2003) who studied several concentrations of Egyptian plant essential oils in vitro and in vivo against $S$. rolfsii and appeared that anise, avocado, blue gum and thyme oils completely inhibited both mycelial growth and sclerotial germination. Behdani el al. (2012) showed that essential oils of anise, cumin, caraway and thyme have a significant effect against $B$. cinerea, on PDA culture, by using the volatile compound production method, essence of cumin, dill, anise, and caraway showed the most inhibition effect. Many other investigators emphasized that the antimicrobial effects of essential oils constitutes are depending on their hydrophobicity and partition in the microbial plasmatic membranes. The effect of specific ions due to their addition in/on plasmatic membrane had a great effect on proton motive force, intracellular, ATP content and all activity of microbial cell, including turgor pressure control, solute transport and metabolism regulation (Lanciotti et al., 2004). The statistical analysis showed that significant differences between fungi, oils of medicinal plants, and the interaction between fungi $x$ oils of medicinal plants were highly significant. 
Table (4): Reduction percentage of mycelial growth of $F$. solani, $F$. moniliforme and $S$. rolfsii on PDA medium mixed with some essential oils (in vitro).

\begin{tabular}{|c|c|c|c|c|c|c|c|}
\hline \multirow{2}{*}{ Fungi } & \multicolumn{7}{|c|}{ Oils of medicinal plants } \\
\hline & Ck. & $\begin{array}{c}\text { A. } \\
\text { graveolens }\end{array}$ & $\begin{array}{c}\text { C. } \\
\text { carvi }\end{array}$ & $\begin{array}{c}\text { C. } \\
\text { cyminum }\end{array}$ & $\begin{array}{c}F . \\
\text { vulgare }\end{array}$ & $\begin{array}{c}P . \\
\text { anisum }\end{array}$ & $\begin{array}{c}N . \\
\text { sativa }\end{array}$ \\
\hline F. solani & 0.00 & 35.56 & 29.26 & 87.41 & 19.63 & 25.26 & 17.04 \\
\hline F. moniliforme & 0.00 & 3.33 & 7.04 & 47.78 & 0.00 & 19.64 & 5.56 \\
\hline S. rolfsii & 0.00 & 2.59 & 29.45 & 77.78 & 0.00 & 0.00 & 0.00 \\
\hline Mean & 0.00 & 13.83 & 21.92 & 70.99 & 6.54 & 14.96 & 7.53 \\
\hline L.S.D at 5 & $(\mathbf{F})$ & Oils of $r$ & $\begin{array}{r}\text { icinal } \mathrm{k} \\
6.5\end{array}$ & ts (O) & & .07 & \\
\hline
\end{tabular}

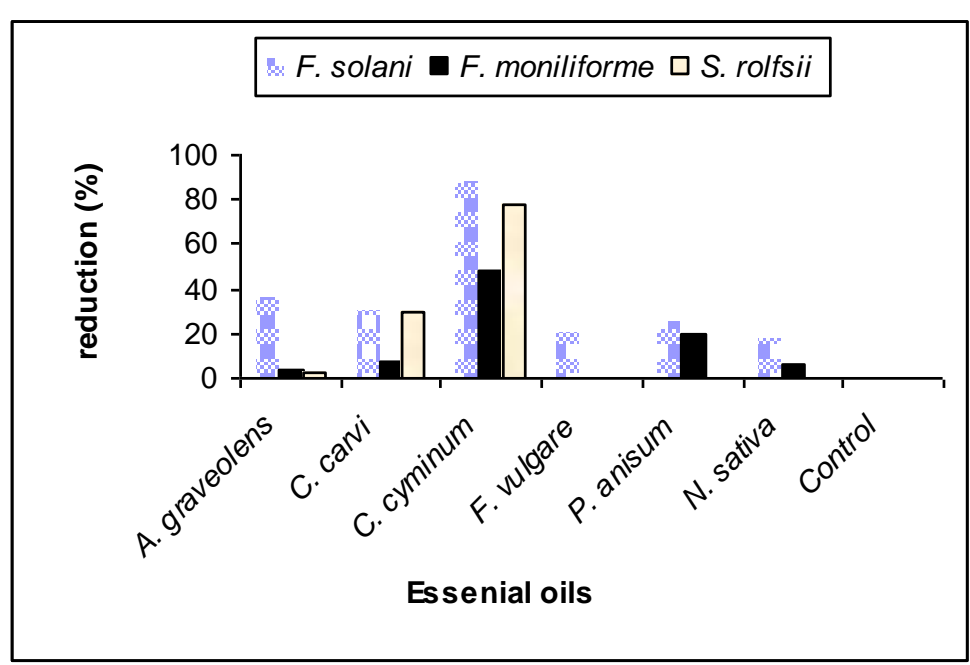

Figure (1): percentage of fungal growth reduction using different plant essential oils $\left(10^{4} \mathrm{ppm}\right)$ on PDA.

3- Effect of some essential oils on sporulation and sclerotia formation:

Data in Figure (2) show that all treatments of the tested essential oils of medicinal plants significantly decreased the sporulation of $F$. solani and $F$. moniliforme compared with check treatment. The highest significant reduction in spores number was observed with the essential oils of $C$. cyminum and $C$. carvi. El- Metwally et al.(2010) reported that, aminogren, cumin, carnation, garlic and rocket oils completely inhibited Botrytis fabae sporulation, these results my due to the antioxidant materials, which found as a major content of these compounds. 


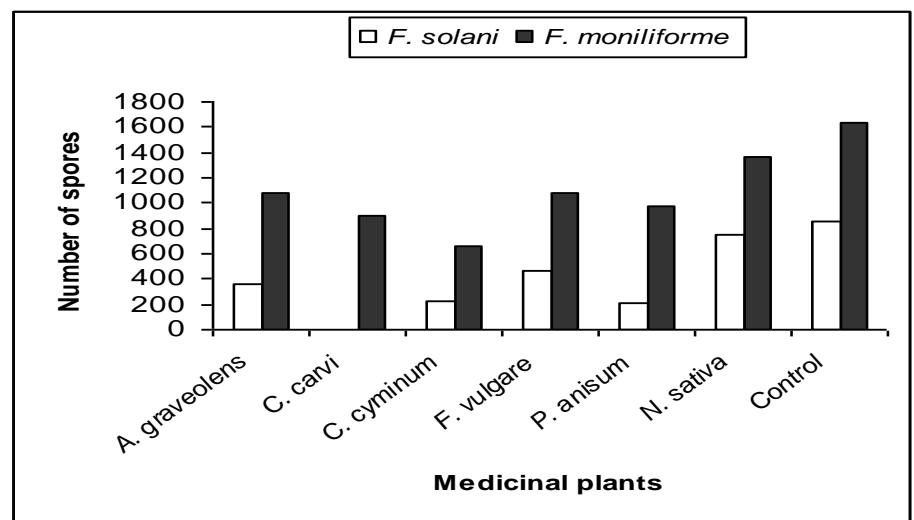

Figure (2): Reduction of Sporulation of F. solani and F. moniliforme on PDA medium mixed with some essential oils (in vitro).

In addition, data in Figure (3) showed that essential oils of $C$. cyminum and $C$. carvi and $P$. anisum were more effective in reducing the sclerotia formation of $S$. rolfsii, while the data showed that the highest values of number of sclerotia formation was obtained with essential oils of $N$. sativa and $A$. graveolens compared with the other treatments. These results are in agreement with the findings of (Bauimy, 2003) who found that essential oils of anise, avocado, blue gum, cumin and sour orange leaves completely inhibited the sclerotia germination of $S$. rolfsii. The variation between the antifungal activity of the essential oils and other may be due to capability of this oil to: 1- penetrating the fungal cell and or 2- alternation in the fungal metabolism by mutagenic activity of its constitutes (phenolic esters, etc.).

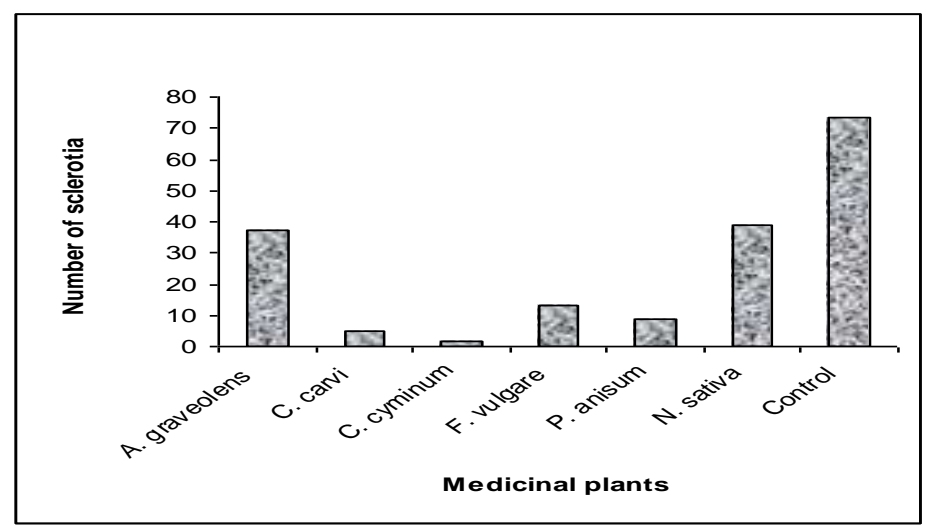

Figure (3): Reduction of sclerotia formation of S. rolfsii on PDA medium mixed with some essential oils (in vitro). 
2- Field experiments:

1 - Effect of intercropping pea with some medicinal plants:

a - On the number of colony forming units (CFU) of microorganisms in the soil:

Data in Table (5) appeared that under field conditions all medicinal plants intercropped with pea increased the number of colony forming units (CFU) of the actinomycets compared with sole pea treatment (check) and the excess was sharply in case of $A$. graveolens, $C$. carvi and $P$. anisum. CFU of bacteria was decreased significantly, as compared with control at both pea growth stages. The same trend cleared in case of fungi especially with $A$. graveolens, $F$. vulgare and $P$. anisum. These results indicated that some medicinal plants might restrain the growth of some soil borne microorganisms, and increase others, which were beneficial to a healthy soil environment for pea. These results are in agreement with the finding of (Chuan et al., 2009) who showed that medicinal plants; Atractylodes lancea and $E$. pekinensis had the strongest inhibitory effect on mould compared with $\mathrm{Ck}$ (mono-cropping peanut), and the CFU of mould in the treatments intercropped with Atractylodes lancea and E. pekinensis was decreased by $53.87 \%$ and $29.59 \%$, respectively. Alternatively, medicinal plants may influence some other component of the soil microflora, which in turn affects the fungus. The statistical analysis showed that the differences between Microbial colony, Medicinal plants, interval (both period) and interaction between Microbial colony $\mathbf{x}$ Medicinal plants $\mathbf{x}$ interval were significant.

Table (5). Effect of medicinal plants intercropped with pea on the microbial population of the soil under field conditions.

\begin{tabular}{|c|c|c|c|c|c|c|c|c|}
\hline Microbial & \multirow{2}{*}{$\begin{array}{l}\frac{0}{N 0} \\
\frac{2}{0} \\
\stackrel{0}{\underline{D}}\end{array}$} & \multicolumn{7}{|c|}{ Medicinal plants } \\
\hline \multirow{3}{*}{ Actinomyces } & & Ck. & $\begin{array}{c}\text { A. } \\
\text { graveolens }\end{array}$ & $\begin{array}{c}\text { C. } \\
\text { carvi }\end{array}$ & $\begin{array}{c}\text { C. } \\
\text { cyminum }\end{array}$ & $\begin{array}{c}F . \\
\text { vulgare }\end{array}$ & $\begin{array}{c}P . \\
\text { anisum }\end{array}$ & $\begin{array}{c}N . \\
\text { sativa }\end{array}$ \\
\hline & $a$ & 3 & 10 & 10 & \begin{tabular}{l|l}
3 & \\
\end{tabular} & 7 & 13 & 3 \\
\hline & $b$ & 2 & 12 & 22 & 5 & 10 & 15 & 6 \\
\hline \multirow[t]{2}{*}{ Bacteria } & $\mathrm{a}$ & 74 & 6 & 40 & 10 & 15 & 4 & 31 \\
\hline & $\mathrm{b}$ & 70 & 12 & 48 & 15 & 17 & 3 & 30 \\
\hline \multirow[t]{2}{*}{ Fungi } & $a$ & 5 & 2 & 2 & 5 & 1 & 1 & 5 \\
\hline & $\mathrm{b}$ & 6 & 1 & 2 & 2 & 1 & 1 & 5 \\
\hline Total & & 26.67 & 7.16 & 20.67 & 6.67 & 8.50 & 6.17 & 13.33 \\
\hline \multicolumn{9}{|c|}{ L.S.D. 5\% = Medicinal plants (M) - Microbial colony (C) - Intervals (I) - M x I - M x C } \\
\hline & 47 & $\begin{array}{r}M \times C \\
0.42\end{array}$ & 3.28 & & & 0.43 & 2.69 & 1.36 \\
\hline
\end{tabular}

In this study, eight of fungal genera were identified in the treatments, including common soil borne fungi; Aspergillus spp. and Alternaria spp. Data inTable (6) show that the treatment of sole pea (control) had the common soil borne fungi; Aspergillus spp, Penicillium spp. and Alternaria spp in addition to the pathogenic fungi; Fusarium spp. and Rhizoctoni solani. In case of the intercropping treatments Fusarium spp. was isolated from the rhizosphere of the soil of the intercropping with $C$. cyminum only and $R$. solani with the 
intercropping with $C$. cyminum and $N$. sativa. While two pathogens of pea in addition to Alternaria spp. were found in the mono-cropping soil, those pathogens did not exist in $C$. carvi and $F$. vulgare intercropping treatments. Ismail (2005) reported that the reduction in the dry weight of tested fungi with intercropping might be due to some of these root had inhibitory substances such as phenolic substances.

Table (6). Effect of medicinal plants intercropped with pea on genera of fungi in soils guiding with morphological colony identification.

\begin{tabular}{|l|c|c|c|c|c|c|c|}
\hline \multicolumn{1}{|c|}{ Fungi } & \multicolumn{7}{c|}{ Medicinal plants } \\
\cline { 2 - 8 } & Ck. & $\begin{array}{c}\text { A. } \\
\text { graveolens }\end{array}$ & $\begin{array}{c}\text { C. } \\
\text { carvi }\end{array}$ & $\begin{array}{c}\text { C. } \\
\text { cyminum }\end{array}$ & $\begin{array}{c}\text { F. } \\
\text { vulgare }\end{array}$ & $\begin{array}{c}\text { P. } \\
\text { anisum }\end{array}$ & $\begin{array}{c}\text { N. } \\
\text { sativa }\end{array}$ \\
\hline Asperigillus spp. & + & + & + & & + & + & + \\
\hline Penicillum spp & + & & & & & & \\
\hline Trichoderma spp. & & & + & & + & & \\
\hline Fusarium spp & + & & & + & & & \\
\hline R. solani. & + & & & + & & & + \\
\hline Epicocum spp. & & & & & + & + & + \\
\hline Rhizopus spp. & & & & & & + & + \\
\hline Alternaria spp. & + & + & & + & & & + \\
\hline
\end{tabular}

\section{b - On pea damping off and disease severity of downy mildew:}

This experiment was conducted during the successive seasons (2007/2008) and (2008/2009) to study the effect of intercropping pea with some medicinal plants (A. graveolens, C. carvi, C. cyminum, F. vulgare, $P$. anisum and $N$. sativa) on wilt, root rot and downy mildew and some growth characters. In this respect, (Table 7) show that the intercropping in the first season 2007/2008 incited a significant reduction in pre-emergence dampingoff of pea intercropped with $C$. carvi, $N$. sativa and $F$. vulgare with averages of $32.76,44.15$ and $44.29 \%$, respectively. Also a significant reduction was cleared in case of the post emergence with the treatments intercropped with P. anisum, A. graveolens and sole pea with averages of 2.00, 2.58 and $3.00 \%$, respectively. Decreasing percentage of infection with wilt and root rot under intercropping conditions might be due to root exudates of various used crop which caused change in total count microflora in rhizosphere region (Botros, 1988; Ismail, 1994 and Chuan et al., 2009). Similar results were obtained by (El Gindy, 2003) who reported that intercropping four faba bean cultivars individually with each of fenugreek, coriander, anise, and caraway under field conditions decreased the incidence of chocolate spot than control because of the effect of medicinal plants odors with superiority of fenugreek and coriander as medical plants. Also Sahar (2006) reported that intercropping faba bean with each of onion, garlic and caraway reduced significantly chocolate spot severity caused by $B$. fabae under greenhouse and field conditions. In the second season, similar trend of results was detected with minor variation in the treatments rank. Healthy survival pea plants were increased in case of pea intercropped with C. carvi, $P$. anisum, $F$. vulgare and $A$. graveolens in first season 2007/2008 with the average of $60.81,52.00,51.71$ and $51.14 \%$, respectively. On the other hand, the same 
four medicinal plants had the same arrangement in the second season with averages of $66.53,60.67$, and $66.53 \%$, respectively. The Statistical analysis showed that the differences between the intercropping treatments were significant for pre and post emergence damping-off and for survival percentage

Data in Table (7) also show that intercropping pea with C. carvi and $F$. vulgare plants was more effective in decreasing percentage of disease severity of downy mildew with an average of $20.23 \%$ for both in the first season, followed by intercropping with $P$. anisum and $A$. graveolens with the averages of 22.27 and $22.90 \%$, respectively. Also, the same trend cleared in the second season where the intercropping with $F$. vulgare was more effective in reducing disease severity with an average of $20.20 \%$ followed by C. carvi, A. graveolens and P. anisum with averages of 20.58, 21.27and $22.83 \%$, respectively. These results are in agreement with results obtained by (Omar et al., 1993) who found that greatest reduction of chocolate spot disease severity was observed when broad bean was intercropped with caraway followed by broad bean + anise, broad bean + cumin and then broad bean + coriander. Reduction on the disease severity of downy mildew under intercropping conditions might be due to changes in the total count of microflora in phelosphere compared with total count of microflora in phelosphere region in sole cropping. In case of intercropping systems, there are two types of plants, one of them a host to the pathogenic fungi and the other non host, and this lead to reducing total count of spores of the pathogenic fungi and cannot reach to inocula potential caused a disease (Ismail, 1994 and Ismail et al., 2000). Potential active chemical constituents of caraway and peppermint are reported by several workers in different fields. Caraway fruits contain $1-6 \%$ of essential oils consisting of about 30 compounds, from which carvone and limonene represent the main portions, about $95 \%$, it is well documented that fruit medicinal and aromatic plants release. (Sedlakova et al., 2003)

Table (7): Effect of pea intercropping with some medicinal plants on its infection with some damping-off and downy mildew diseases.

\begin{tabular}{|c|c|c|c|c|c|c|c|c|c|c|}
\hline \multirow[t]{3}{*}{ Treatments } & \multicolumn{6}{|c|}{ Damping-off } & \multirow{2}{*}{\multicolumn{2}{|c|}{ Survival }} & \multirow{2}{*}{\multicolumn{2}{|c|}{$\begin{array}{l}\text { Disease } \\
\text { severity of } \\
\text { downy } \\
\text { mildew }\end{array}$}} \\
\hline & \multicolumn{2}{|c|}{ Pre } & \multicolumn{2}{|c|}{ Post } & \multicolumn{2}{|c|}{\begin{tabular}{|c|} 
Total \\
damping-off
\end{tabular}} & & & & \\
\hline & $1 \mathrm{st}$ & 2nd & 1 st & 2nd & 1st & 2nd & 1st & 2nd & 1st & 2nd \\
\hline Sole pea & 47.71 & 38.67 & 3.00 & 2.57 & 50.77 & 41.24 & 49.72 & 58.00 & 25.92 & 24.67 \\
\hline Pea + A. grave & 46.29 & 37.34 & 2.58 & 3.00 & 48.87 & 40.34 & 51.14 & 59.67 & 22.90 & 21.27 \\
\hline Pea + C. carvi & 32.76 & 25.41 & 6.43 & 8.05 & 39.19 & 33.46 & 60.81 & 66.53 & 20.23 & 20.58 \\
\hline Pea + C. cyminum & 49.57 & 41.17 & 4.15 & 4.15 & 53.72 & 45.32 & 46.29 & 54.01 & 26.00 & 26.10 \\
\hline Pea + F. vulgare & 44.29 & 35.00 & 4.00 & 5.33 & 48.29 & 40.33 & 51.71 & 60.67 & 20.23 & 20.20 \\
\hline Pea + P. anisum & 46.00 & 37.00 & 2.00 & 2.33 & 48.00 & 39.33 & 52.00 & 60.67 & 22.27 & 22.83 \\
\hline Pea + N. sativa & 44.15 & 34.83 & 6.14 & 7.17 & 50.29 & 42.00 & 49.72 & 58.01 & 25.73 & 25.63 \\
\hline L.S.D at $5 \%$ & 5.67 & 3.53 & 1.92 & 2.62 & & & 2.85 & 6.34 & 3.33 & 4.22 \\
\hline
\end{tabular}




\section{c - On some pea growth characters:}

Results in Table (8) were confirmed from experiments in seasons $2007 / 2008$ and 2008/2009 concerning fresh weights, the results of the first season revealed variations among the treatments where pea fresh weight was increased significantly in case of intercropping with $C$. carvi, $A$. graveolens and $P$. anisum compared with sole pea. When the plants intercropped with $C$. carvi the average fresh weight was $8.04(\mathrm{~g})$. In contrast, the lowest fresh weight was found in pea intercropped with $C$. cyminum and $N$. sativa. These results are close to that obtained in the second season, where the highest value of fresh weight was found in pea $+C$. carvi with an average of $7.96(\mathrm{~g})$ followed by pea $+F$. vulgare, pea+ $A$. graveolens and pea+ $P$. anisum with averages of $7.91,7.28$ and $7.21(\mathrm{~g})$, respectively. Dry weight of pea in first season showed the highest values with pea intercropped with either C. carvi or A. graveolens, with the averages of 4.10, 4.03 and in the second season with average of 4.50 , and $4.43(\mathrm{~g})$, respectively. The highest values of 100 seeds were observed with pea intercropped with $C$. carvi, F. vulgare and $A$. graveolens with averages of 21.31, 19.91 and 19.11 (g), respectively in the first season. In the second season the same trend was noticed where pea intercropped with $C$. carvi, $A$. graveolens and $F$. vulgare had the highest weight of 100 seeds with the averages of 22.71, 22.11 and $20.44(\mathrm{~g})$, respectively. Statistical analysis showed that the differences between the intercropping treatments were significant for fresh and dry weight and weight of 100 seeds $(\mathrm{g})$.

Table (8): Effect of pea intercropped with some medicinal plants on some pea growth characters.

\begin{tabular}{|l|c|c|c|c|c|c|}
\hline \multirow{2}{*}{ Treatments } & \multicolumn{2}{|c|}{$\begin{array}{c}\text { Fresh } \\
\text { plant /weight } \\
\text { (gm) }\end{array}$} & \multicolumn{2}{c|}{$\begin{array}{c}\text { Dry } \\
\text { plant /weight } \\
\text { (gm) }\end{array}$} & \multicolumn{2}{c|}{$\begin{array}{c}\text { Weight of 100 seeds } \\
\text { (gm) }\end{array}$} \\
\cline { 2 - 7 } & 1st & 2nd & 1 st & 2nd & 1 st & 2nd \\
\hline Sole pea & 6.37 & 6.94 & 3.80 & 4.20 & 16.99 & 18.99 \\
\hline Pea + A. graveolens & 7.55 & 7.28 & 4.03 & 4.43 & 19.11 & 20.44 \\
\hline Pea + C. carvi & 8.04 & 7.96 & 4.10 & 4.50 & 21.31 & 22.71 \\
\hline Pea + C. cyminum & 5.00 & 5.60 & 2.45 & 2.85 & 16.09 & 17.61 \\
\hline Pea + F. vulgare & 6.93 & 7.91 & 3.69 & 4.09 & 19.91 & 22.11 \\
\hline Pea + P. anisum & 7.44 & 7.21 & 3.79 & 4.19 & 16.26 & 18.39 \\
\hline Pea + N. sativa & 5.01 & 5.68 & 3.08 & 3.48 & 11.92 & 13.32 \\
\hline L.S.D at 5\% & 0.71 & 0.77 & 0.73 & 0.73 & 1.91 & 2.25 \\
\hline
\end{tabular}

\section{REFERENCES}

Abdala, K.A.; Ali, H.Y. and Mansour, M.S. (1992). Phytopathological studies on damping-off and root-rot diseases of pea in A.R.E. Egypt. J. Appl. Sci., 7 (9): 242-261.

Allen, O.N. (1953). Experiments on soil-Bacteriology. Burgess Publishing Co., Minneapolis. $127 \mathrm{pp}$.

Altieri, M. A. (1999). The ecological role of biodiversity in agroecos systems. Agriculture Ecosystems and Environment. 74:19-31. 
Atia, M.M. (1995). Studies onroot-rot disease of some cucurbits in reclaimed land. M. Sc. Thesis, Fac. Agric., Zagazig Univ,

Bauiomy, M.A.M. (2003). Using essential oils in controlling southern blight disease in peanut. Egypt.J.Appl. Sci., 18 (5) 53-72.

Behdani, M.; Pooyan, M. and Abbasi, S. (2012). Evalution of antifungal activity of some medicinal plants essential oils against Botrytis cinerea, caused agent of postharvest apple rot, in vitro. International Journal of Agriculture and Crop Sciences. 4 (14), 1012-1016.

Blaser, B.C.; Singer, J.W. and Gibson, L.R. (2007). Winter cereal, seedling rate and intercrop seedling rate effect on red clover yield and quality. Agron. J., 99: 723- 729.

Boddle, T. (1982). Entromologists probe chemical defenses and natural enemies. Bio- science 32: 308-311.

Botros, S.E. (1988). Studies on root and stalk-rot of maize. M. Sc. Thesis, Fac. Agric. Assiut Univ.

Burkett-Cadena, M.; Kokalis-Burelle, N.; Lawrencem, K.S.; Van Santen, E. and Kloeper, J.W. (2008). Suppressiveness of root-knot nematodes mediated by rhizobacteria. Biol. Control, 47: 55-59

Christensen, C.M. (1957). Deterioration of stored grains by fungi. Bot. Rev., 23: $108-134$.

Chuan, C.D; Hui, X;Xing, X.W; Per, D.; Yi, I.L. and Xiao, T. (2009). Intercropping peanut with traditional Chinese medicinal plants improves soil microcosm environment and peanut production in subtropical China. African Journal of Biotechnology. 8 (16), 3739 - 3746.

Cown, M.M (1999). Plant products as antimicrobial agents. Clinical Microbiology Reviews. 12: 564-582.

Daoud, A.S.; Qasim, N.A.; AL-Mallah, N.M. (1990). Pcomparison study on the effect of some plant extracts and pesticides on some phytopathogenic fungi. Mesopotamia J. Agric. 22: 227- 235.

Das, K; Tiwari, R.K.S. and Shrivastava, D. K. (2010). Techniques for evaluation of medicinal plant products as antimicrobial agent: Current methods and future trends. Journal of Medicinal Plants Research Vol. 4 (2), pp. 104-111.

El Gindy, Hala M. R. (2003). Studies on chocolate spot disease of faba bean. M. Sc.Thesis, Fac. Agric., Minufiya University.

El-Metwally, M.A; Ghanem, Kh.M. and Abd El-Hai, K.M. (2010). Improving the performance of faba bean and controlling of chocolate spot disease using bio- compound. Plant pathology. (4): 169-178.

Gilman, J.B. (1957). A Manual of soil fungi. lowa State College Press, U.S.A. 450pp.

Gomez, K.A. and Gomez, A.A. (1984). Statistical procedures for agricultural research 2 nod, John Weley and Sons, Inc., New York.

Hagedorn, D.J. (1991). Handbook of pea diseases A1167. University of Wisconsin- Extension, Madison.

Hansen, H.N. (1926). A simple method of obtaining single spore culture, Science (N.S.) 64-384.

Hauggaard, H.N.; Jornsgaard, B.; Kinane, J. and Jensen, E. S. (2007). Grain legume- cereal intercropping: The practical application of diversity 
competition and facilitation in arable and cropping system. Renewable Agriculture and food systems. 23 (11): 3-12.

Ismail, A.E.A. (2005). Effect of intercropping of faba bean (Vicia faba L.) with some vegetables on the infection of faba bean with orobanche and some fungal diseases.J. Agric, Sci. Mansoura Univ., 30 (8): 4593-4603.

Ismail, A.E.A. (1994). Effect of intercropping of soybean and maize plants on incidence of soil fungal diseases. Ph. D. Thesis. Fac. Agric., Zagazig Uni. Egypt.

Ismail, A.E.A.; El-laithy, B.E.A. and Siham M. Abd El-Ghafour (2000). Effect of maize - soybean intercropping on some foliar fungal diseases and crop characteristics. J. Agric Sci. Mansoura Univ. 25(9):5633.

Jens, C.F.; Thanc, V. and Mathur, S.B. (1991). An illustrated manual on identification some seed- borne Aspergilli, Fusaria, Penicilia, and their Mycotoxins. Danish Government, Institute of Seed Pathology for Countries, Ryvans Alle 78, Dk, 2900 Hellerue, Denmark. (c.f. CABI Data base Abstracts).

Kabura, B.H., Musa, B. and Odo, P.E. (2008). Evaluation of the yield components and yield of onion (Allium cepa L.)- pepper (Capsicum annum L.) intercrop in the Sudan savanna. J. ARON., 7: 88-92.

Kucharek, T. (2004). Florida plant disease management guide: Okra. Plant Pathology Department document PDMG-V3-41. Florida Cooperative Extension Service, Institute of Food and Agricultural Sciences, University of Florida, Gainesville, FL.

Lestie, J.F. and Summerell, B.A. (2006). The Fusarium Laboratory Manual. Blackwell Publishing Ltd., Oxford, U.K.

Malkhan, S.G.; Shahid, A.; Masoodm, A.; Kangabam, S.S.(2012). Efficacy of plant extracts in plant disease management. Agricultural Sciences 3. (3): 425-433.

Martin, J.P., (1950). Use of acid rose Bengal and streptomycin in the plate method for estimating soil fungi. Science, 69: 215.

Nour-Jehan M.M. Eisa (2003). Relation between damping-off and root rot disease of pea and both of phenol contents and hydrolytic enzymes activity. Egypt. J. Appl. Sci., 18 (8): 12-23.

Omar, S.A.; Rahhal, M.M.; A.A. Hila and Zayed, A. (1993). Infuence of intercropping of bean with some medicinal plants on disease severity of chocolate spot and rust and seed yield. Annals Agric Sci., Sp. Issue, 2, 551-560.

Ozan, M. (2003). Antifungal effects of some Turkism apice essential oils Aspergillus niger and Botrytis cinerea growth. Agrimedia Gmbh. 8: 173175.

Riker, A.J. and Riker, R.S. (1936). Introduction to research on plant disease. lohn, S. Swig, Co., St., New York, 117pp.

Sahar A.M. Zayan (1995). Studies on downy mildew of peas. M. Sc.Thesis, Fac. Agric., Cairo Univ.,

Sahar, Abbas El-Sayed (2006). Use of intercropping and other treatments for controlling faba bean diseases. Ph.D. Thesis, Fac. Agric., Minufiya University. 


\section{Mohamed, Gehad M.}

Sardana, S.; Mahajan, R.K.; Gautam, N.K. and Ram, B. (2007). Genetic variability in pea (Pisum sativum) germplasm for utilization. SABRAO Journal of Breeding and Genetics, 39(1): 31-41.

Sedlakova J., Kocourkova, B., Lojkova, L.,Kuban, V. (2003).The essential oil content in caraway species (Carum carvi L.). Hort. Sci. 30(2):73-79.

Skinner, F.A.; Jones, P.G. and Molison, J.E. (1952). Acomparison of a direct and a plate counting technique for quantitative count of soil microorganisms. J. Gen. Microbiol., 6: 261.

Smartt, J. (1990). Grain legumes: Evolution and Genetic resources. Cambride University Press Cambridge, UK.

Smith, S.N. (2007). An overview of ecological and habitat aspects in the genus Fusarium with spcial emphasis on the soil-borne pathogenic forms. Plant Pathology Bulletin, 16: 97-120.

Thakur, R.N.; Singh, P. and Khosla, M.K. (1989). In vitro studies on antifungal activities of some aromatic oils. Indian perfumer. 33 (4):257-260.

Warkentin, T.D.; Rashid, K.Y. and Xue, A.G. (1996). Fungicidal control of powdery mildew in field pea. Can. J. Plant Science. 77: 307-310.

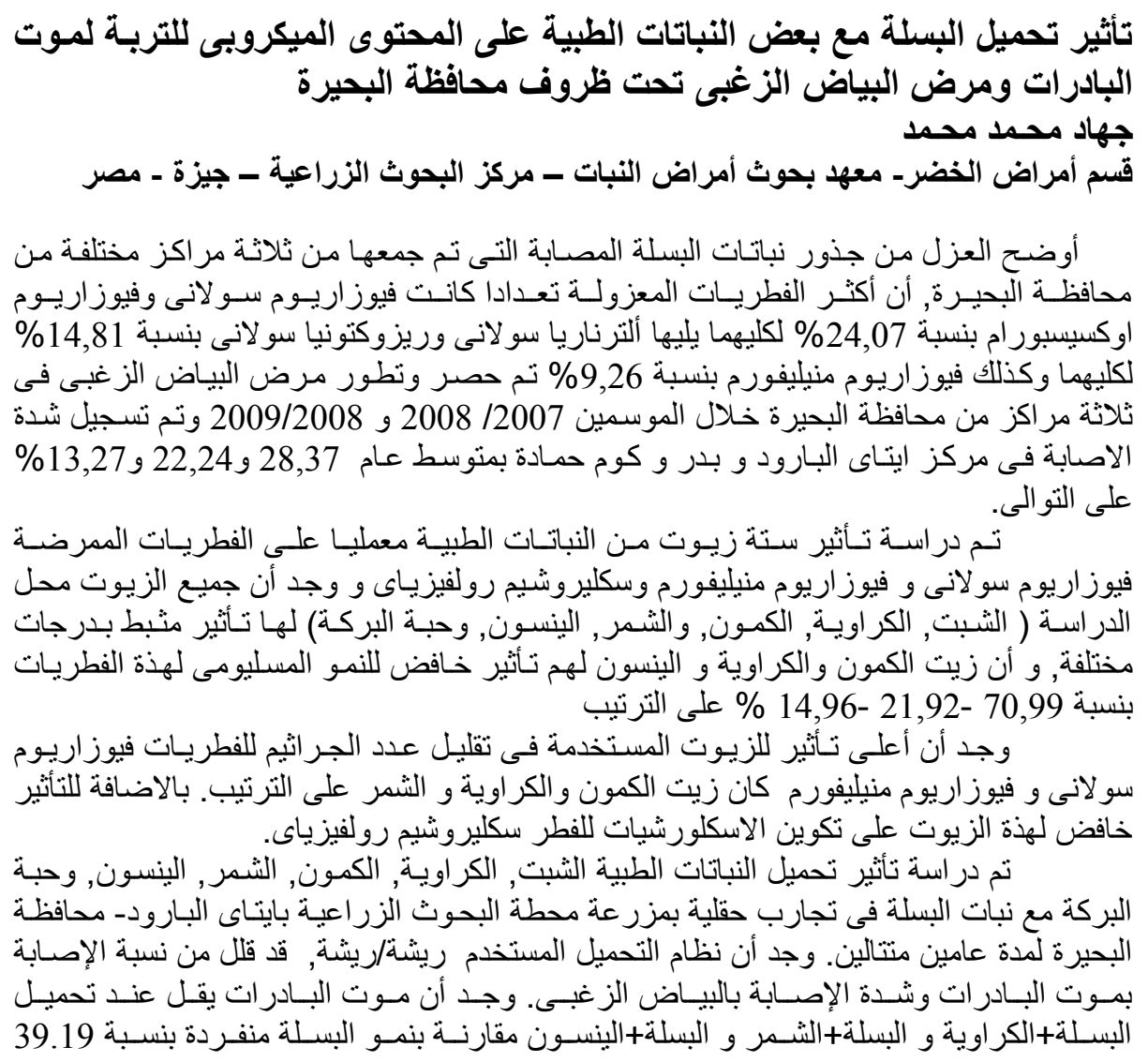


و48.55 و 48.29 \% على الترتيب خلال الموسم الزر اعى 233,46 و 2008/2007 وقلل من نسـة الاصـابة

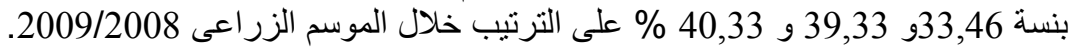

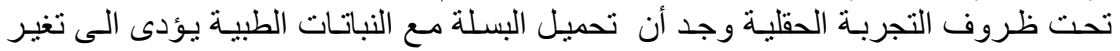

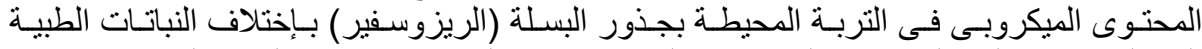

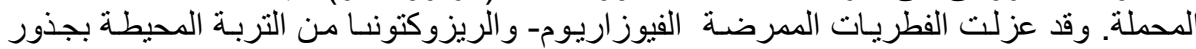

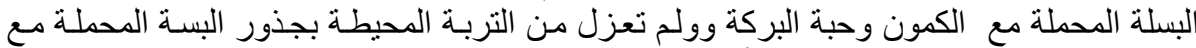

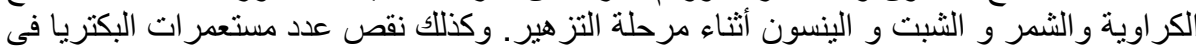

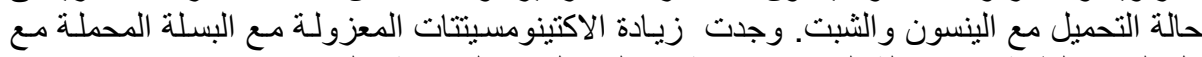

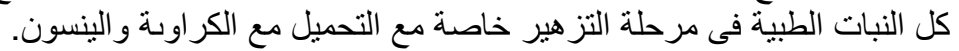

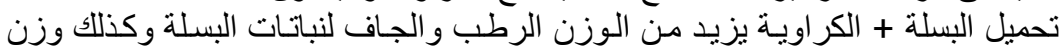

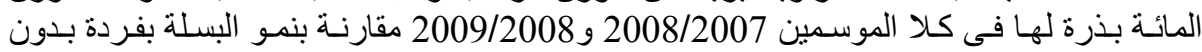

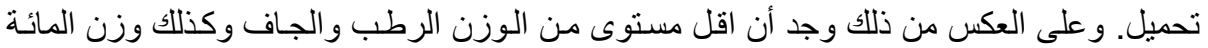
بذرة كان عند تحميل البسلة مع الكمون وحبة البركة.

كلية الزراعة ـ جامعة المنصورة مركز البحوث الزراعيه
قام بتحكيم البحث

أ.د / محمد الششتاوى عبد ربه

أ.د / محمد مجدى حمزه الدثناوى 